\title{
Teaching Ethics in Higher Education Using the Values - Issues - Action (VIA) Model
}

\author{
Crystal Chambers and Hellen Ransom \\ East Carolina University, Greenville, NC, USA
}

\author{
chambersc@ecu.edu ransomh@ecu.edu
}

\begin{abstract}
Ethics content within higher education graduate programs can help higher education students as emerging leaders become more thoughtful about the decision making process. The purpose of the present manuscript is to explore one vehicle through which current and future higher education leaders can actively contemplate their values and how their values influence their actions when faced with an ethical challenge. The Values - Issue - Action (VIA) Model for Ethical Decision Making is a tool for both classroom use and professional reflection through which one can reflect on their values (V) and how those values shape how they perceive issues (I), and in turn shape their actions (A). Implications for teaching, learning, and practice are discussed.
\end{abstract}

Keywords: Ethics, Graduate Education, Professional Programs, Leadership

\section{Introduction}

Higher education leaders regularly face challenges with ethical dimensions. Ranging from the routine or mundane, such as inappropriate parental inquiries into student academic performance, to salacious corruption, such as the child sex abuse scandal at Pennsylvania State University, leaders are tested in their ethical decision making capacities. Some leaders, like the University of Virginia's, Teresa Sullivan in the wake of a falsified fraternity gang rape report, emerge from real and purported ethical breaches by focusing university resources towards raising awareness and improving institutional processes and procedures. Others, like the University of Illinois' Phyllis Wise become entrenched, standing by ill-advised actions, and in spite of all of their other accomplishments, forfeit their turn at the institution's helm.

The question is not whether a leader will be tried, but when. Bollman and Gallos (2011, p. 9) impart that "leadership success rests in the quality of the choices made by leaders, and leaders make better choices when they are mindful about their thought processes and actions." Ethics content within higher education graduate programs can help higher education students as emerging lead-

Material published as part of this publication, either on-line or in print, is copyrighted by the Informing Science Institute. Permission to make digital or paper copy of part or all of these works for personal or classroom use is granted without fee provided that the copies are not made or distributed for profit or commercial advantage AND that copies 1) bear this notice in full and 2) give the full citation on the first page. It is permissible to abstract these works so long as credit is given. To copy in all other cases or to republish or to post on a server or to redistribute to lists requires specific permission and payment of a fee. Contact Publisher@,InformingScience.org to request redistribution permission. ers become more thoughtful about the decision making process.

The purpose of the present manuscript is to explore one vehicle through which current and future higher education leaders can actively contemplate their values and how their values influence their actions when faced with an ethical challenge. The Values - Issue - Action (VIA) Model for Ethical Decision Making is a tool for both classroom use and

Blind Peer-Reviewed Article. Editor: Sydney Freeman, Jr.

Submitted: September 1, 2015; Revised: December 10, 2015; Accepted: December 15, 2015 
personal reflection one can reflect on their values $(\mathrm{V})$ and how those values shape how they perceive issues (I), and in turn shape their actions (A). This paper begins with a general discussion of ethics in higher education followed by the role and limits of professional codes in decision making processes. A description of the VIA Model within the context of other ethical decision making models, emphasizing the role of values, follows with three applications within the higher education context. Implications for teaching, learning, and practice are discussed.

\section{Ethics in Higher Education}

When most people think about ethics they think of how actions are determined to be either right or wrong. The questions that spring from this reflective process rely on the systematization, justification, and application of various guiding theories (Deigh, 2010). Many in western society are influenced by Aristotle's thought that equals should be treated as equals, Robert Nozick's views on entitlement, John Rawls' emphasis on justice and fairness, Alasdar MacIntyre's justice as desert, and many other philosophical thoughts and moral teachings (Beauchamp \& Childress, 2001). These normative conceptions as developed within philosophical discourse are abstractions that can be brought to bear on ethical issues in higher education through application.

Applied or practical ethics is oriented towards a specific context or set of facts. The concept of applied ethics provides a means for individuals and even the organizations to examine ethical issues (The Council for Industry and Higher Education [CIHE], 2005). As described by Bernhardt (2014, p. 2), "when we study applied ethics, we're often trying to find solutions to specific moral problems." Within the context of higher education, particular areas of consideration include, but are not limited to, bribery in admissions and accreditation, embezzlement and other financial fraud, degree mills, plagiarism, nepotism, research falsification, and cheating (Heyneyeman, 2013). Corruption, abuse of one's authority for material or personal gain, in higher education is geographically widespread and is spawned by increasingly competitive academic environments and increasing returns to higher education (Heneyman, 2010), conditions described by Slaughter and Rhodes (2004) as commodification. Institutions in Latin America and the Middle East are perceived as the most corrupt, while higher income Asian countries as well as those in Western Europe being perceived as being corrupt, but having less corruption (Heneyeman, Anderson, \& Nurliyeva, 2008). No area of the globe is unscathed.

Short of corruption, many ethical shortcomings of higher education leaders fall in the realm of professional ethics, lapses thereof. Rather than individuals concertedly seeking to raise prospects for themselves or others through inappropriate means, they face challenging dilemmas, are presented with conflicts of interests, and make choices suboptimal from an ethical perspective. Here it may be useful to consider examples from Pennsylvania State University (Penn State) and The University of Illinois to distinguish poor ethical choices from corruption.

In the wake of investigation into Penn State Assistant Football Coach Jerry Sandusky's sexual abuse of multiple minors, three university officials were charged with perjury, obstruction of justice, and failure to report the crime (as of July 2015, four years later, they have yet to stand trial). Both money and a university athletics legacy were at stake. The beloved coach of the Penn State Nittany Lions was Joe Paterno, the winningest college football coach in U.S. history: 409 total wins, 37 bowl victories, and 18 credited bowl championships over his 35 year career at Penn State. Penalties for the cover up included firings and resignations of several university officials, the removal of Paterno's statute from campus, the stripping of six bowl wins, $\$ 60$ million in sanctions, a four year suspension from bowl appearances with concomitant revenue shares, and a loss of half of their NCAA football scholarships (Consent Decree, 2012; ESPN.com, 2012, 2015; Paterno, 2014). Proactive inquiry into Sandusky's behavior would have gotten in the way of big football. According to an independent investigation, university officials were negligent in their failure to report child sexual abuse, actively engaged in concealing Sandusky's inappropriate 
conduct with children, and further endangered one child by revealing the identity of an anonymous complainant to Sandusky (Freeh Sporkin, \& Sullivan LLP, 2012). While the university and family of Joe Paterno continue to fight these charges in the court of public opinion (Paterno, 2014), this example is one of corruption. And corruption in the academic context rewards with victories that are at most pyrrhic. The goals gained - whether college entry, degree attainment or football wins - are tarnished by corrupted means (Heneyman, 2010).

By contrast, when Phyllis Wise withdrew the accepted employment offer of Steven Salaita, a tenured associate professor position in American Indian Studies, over controversial comments on Twitter regarding the state of Israel, this was not a case of corruption, but decision making falling short of professional ethics standards. Tenure is a lifetime property right in one's employment earned by faculty after proving their abilities to teach and conduct research over a probationary period which varies by institution, but most often is 6 years (one gains tenure in the seventh) (Meiners, 2004). Like any property right in the United States, it cannot be withdrawn without due process. The purpose of tenure is to protect academic freedom, a globally recognized interest in the ability of faculty to pursue teaching, research, and related scholarly activities without fear of reprisal from the campus (Altbach, 2001). According to the American Association of University Professors (AAUP's) Statement on Professional Ethics, professors have a "primary responsibility to their subject ... to seek and state the truth as they see it" (1966/2009, para. 3). Typically faculty who lose tenured positions do so for reasons of misconduct: drug-related activity, financial fraud (falsification of expenditures), sexual or scientific misconduct. Increasingly, with the proliferation of post-tenure review procedures, there are faculty released for incompetence, lack of research productivity or failure to teach (Kaplin \& Lee, 2013; Olivas, 2006).

However in the case of Salaita, the bases for Wise's action were tweets, an outpouring of condemnation of those tweets from members of the University of Illinois community, particularly donors (personal communications to S. Salaita, 2014; Des Garennes, 2014). As a general matter, social media activity should not be the basis of employment decisions within higher education, unless the matter conveyed via social media violated other institutional policies, such as assault, discrimination, revelation of confidential information, and the like (Kaplin \& Lee, 2013). As a public intellectual, Salaita regularly used Twitter as a dissemination medium. As a scholar of critical studies and indigenous peoples, the tweets in question were within his area of expertise. Arguably, they should have been protected as a matter of academic freedom. By contrast, Phyllis Wise had her own concerns. Wise (2014a) supported the Inclusive Illinois mission and vision: to create one campus of many voices that:

- Fosters a generation of new leaders who appreciate the value of unique identities and experiences.

- Forges relationships between and among groups and people of different backgrounds.

- Creates an environment accepting of difference.

- Celebrates what different communities bring to the University of Illinois.

- Affirms the unique identity of every individual.

- Actively addresses issues of intolerance and insensitivity when they impact any member of our campus community. (Inclusive Illinois, n.d.)

Wise denied that she was influenced by the angry letters from current and prospective students, their parents, alumni, and donors who threatened continued university gifts if Salaita began his employment. Instead, she asserted that her utmost concern was for the campus community (Des Garennes, 2014). In her address, she articulates that her objection was not to Salaita's point of view, but his tonality and perhaps method of dissemination (Wise, 2014b). She perceived 
Salaita's tweets as contradictory to the Inclusive Illinois vision, not seeing that her actions were themselves contradictory thereto. In the spirit of openness and debate which she espouses to value, she could have voiced concerns with his mode of communication while preserving his academic rights. The faculty issued a vote of no-confidence against Wise, for this and her handling of other controversies at the time (Wurth \& Hettinger, 2015). She resigned and Salaita brought two lawsuits which were settled given the publicity and potential liability for violating constitutional rights (Salaita, 2015; Wurth, 2015). With the settlement, Illinois will pay $\$ 875,000$ for Salaita to drop the suits (Cohen, 2015) and Wise's major accomplishments such as the inclusion of Illinois as part of Coursera's first wave of institutional partners are overshadowed by this controversy. As for Salaita, he is now an endowed chair of American Studies at the American University of Beruit and renowned academic freedom martyr.

The situation at Illinois was not a case of corruption, but decision making falling short of professional ethics standards. As administrators strive within ethically cloudy environments to do well (meeting or exceeding expected levels of performance advancing their units) AND do good (contribute positively to the world individually or through the students, faculty and staff in their influential sphere), it is useful to consider frameworks to aid ethical decision making (Reeves, 2010). We begin with a discussion of professional ethical codes.

\section{Professional Codes of Ethics}

Research on professional codes recognizes the importance of leaders being aware of ethical standards (Wood \& Rimmer, 2003). However, with the limited education in ethics for higher education leaders generally (Aziz et al., 2005; Bollman \& Gallos, 2011; Fullan \& Scott, 2009; Gmelch \& Miskin, 1993, 2004; Keenan, 2015; Wright \& Miller, 2007), the numerous standards and codes proliferated by colleges and universities, in addition to professional codes proffered by individual disciplines, many leaders may find themselves inundated with information, but limited in resources to help decision making (CIHE, 2005). In the absence of universal statements on professional ethics in higher education, guidance can be found in the International Association of Universities Statement on Academic Freedom, The Magna Charta Universitatum, The Bucharest Declaration on Ethical Values and Principles of Higher Education in the Europe Region, and The UNESCO Recommendation Concerning the Status of Higher Education Teaching Personnel (International Association of Universities, 2014). In addition Watson (2007, pp. 372-373) distills "ten commandments" for academe:

1. Strive to tell the truth.

2. Take care in establishing the truth.

3. Be fair.

4. Always be ready to explain.

5. Do no harm.

6. Keep your promises.

7. Respect your colleagues, your students, and especially your opponents.

8. Sustain the community.

9. Guard your treasure.

10. Never be satisfied.

Yet even Watson (2007) would argue that there is an over simplicity to this listing, a list that is instructive when faced with the temptation of corruption, shirking of ethical means for expediency. But clear resolution of ethical challenges becomes dubious when applying these in the face of "wicked" problems (Rittel \& Webber, 1973). Given the complexity of wicked problems, it is at best difficult, if not impossible, to render decisions that are pareto optimal: There are often winners and losers. This brings us to the issue of spillovers and externalities. While individuals and organizations can make decisions with the best of intentions, through our knotted web of interde- 
pendence, impacts on innocent or bystander third parties are bound. Third party impacts are never completely mitigated. However, a more circumspect approach to decision making can improve higher education decisions within communities both local and global (Gallant \& Kalichman, 2010).

To improve ethical decision making, the Council for Industry and Higher Education advocates that the best way to increase awareness of ethical decisions is to employ decision making models. These models would not replace ethical policies and procedures, but would be used alongside them as a way to check whether there is congruence between espoused values and demonstrated actions (CIHE, 2005). Using the VIA Model, students of higher education and other professional disciplines can seek resolution to specific ethical dilemmas, moral problems as they arise.

\section{The VIA Model}

Leadership preparation is important to strengthen leaders, imbue decision making strategies, and impart the understanding needed to address complex challenges faced by academe today (Bollman \& Gallos, 2011). Rather than a list of “do's" and “don'ts" ethical leadership is about making good decisions that engender trust and commitment among institutional stakeholders, often resulting in greater satisfaction among campus leaders (Johnson, 2015; Keenan 2015). As reflected by Palmer (2000, p. 78),

A leader shapes the ethos in which others must live, an ethos as light-filled as heaven or as shadowy as hell. A good leader is intensely aware of the interplay of inner shadow and light, lest the act of leadership do more harm than good. (emphasis in original).

The active reflection to which Palmer refers is often missed in higher education leadership preparation (Aziz et al., 2005; Fullan \& Scott, 2009; Gmelch \& Miskin, 1993, 2004; Keenan, 2015; Wright \& Miller, 2007). Indeed Keenan (2015) likens the lack of prevalence of higher education ethics to that of the Catholic Church, wherein parishioners, like students, come to the institution for ethical development, but those in an instructive capacity have limited means to act ethically when faced with challenges.

The Values - Issue - Action (VIA) model for ethical decision making is designed to help leaders reflect on their values, prioritize competing values, and provide a means for resolving these issues ethically. Ethical decision making models are useful tools that "help inform the practice of successful leadership in the face of ever-increasing complexities in higher education" (Wilcox \& Ebbs, 1992, p. iv). In his synthesis of ethical decision making models, Jones (1991) places the process of ethical decision making situationally within social, cultural, economic, and organizational contexts, beginning the decision process with the presentation of an ethical issue even if not recognized as such, and the individual proceeds without critical reflection in default mode, although critical engagement is much more preferred (Ferrell \& Gersham, 1985; Hunt \& Vitell 1986; Rest, 1986; Trevino, 1986) (See Figure 1). Second, a judgment is made wherein an individual processes the ethical dimensions of the issue. This process has been explored through moral development (Rest, 1986; Trevino, 1986) as well as cognitive dimensions (Dubinsky \& Loken, 1989; Hunt \& Vitell 1986). Third, these judgments are postulated to establish an ethical intent which is moderated situationally by conditions, individuals, and opportunities (Dubinsky \& Loken, 1989; Ferrell \& Gersham, 1985; Trevino, 1986). Finally each of these components feed into one's propensity to engage in ethical behavior. Gallant and Kalichman (2010) offer a simplified version of this model wherein an ethical challenge arises and that an individual makes a decision to act that is moderated on his/ her knowledge, skills, and attitudes. This decision, in turn, directs behavior. 

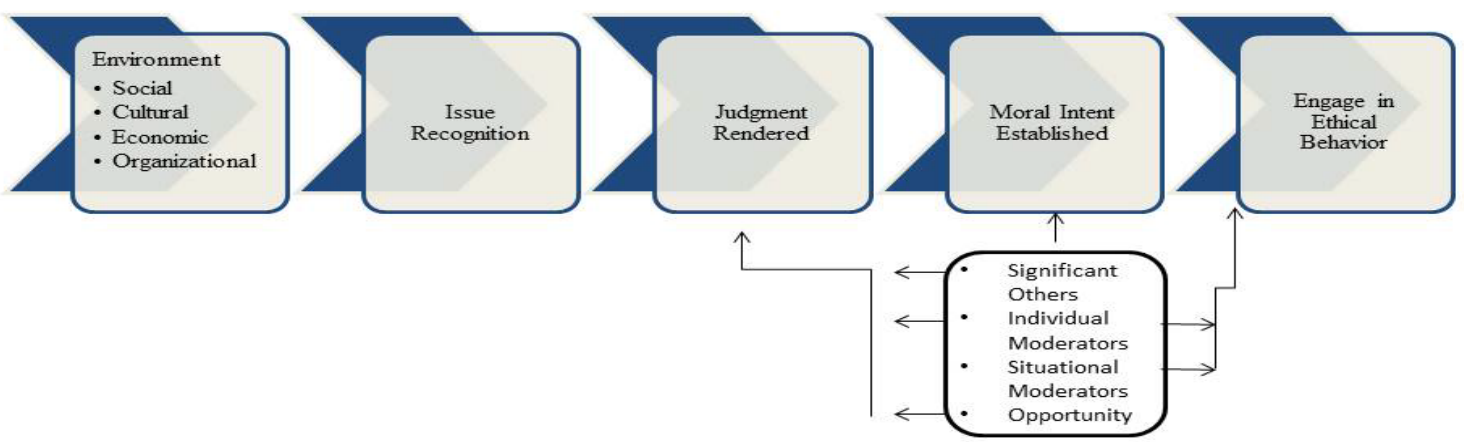

Figure 1. Synthesis of ethical decision making models adapted from Jones (1991)

The VIA model adds to this framework in a couple of ways. First, in terms of placement, we physically place the entire decision making process within social, cultural, economic, and organizational contexts. Second, before ethical challenges present themselves, individuals have values, normative virtues they hold dear, and posit that an individual meets ethical challenges with that value set (See Figure 2).

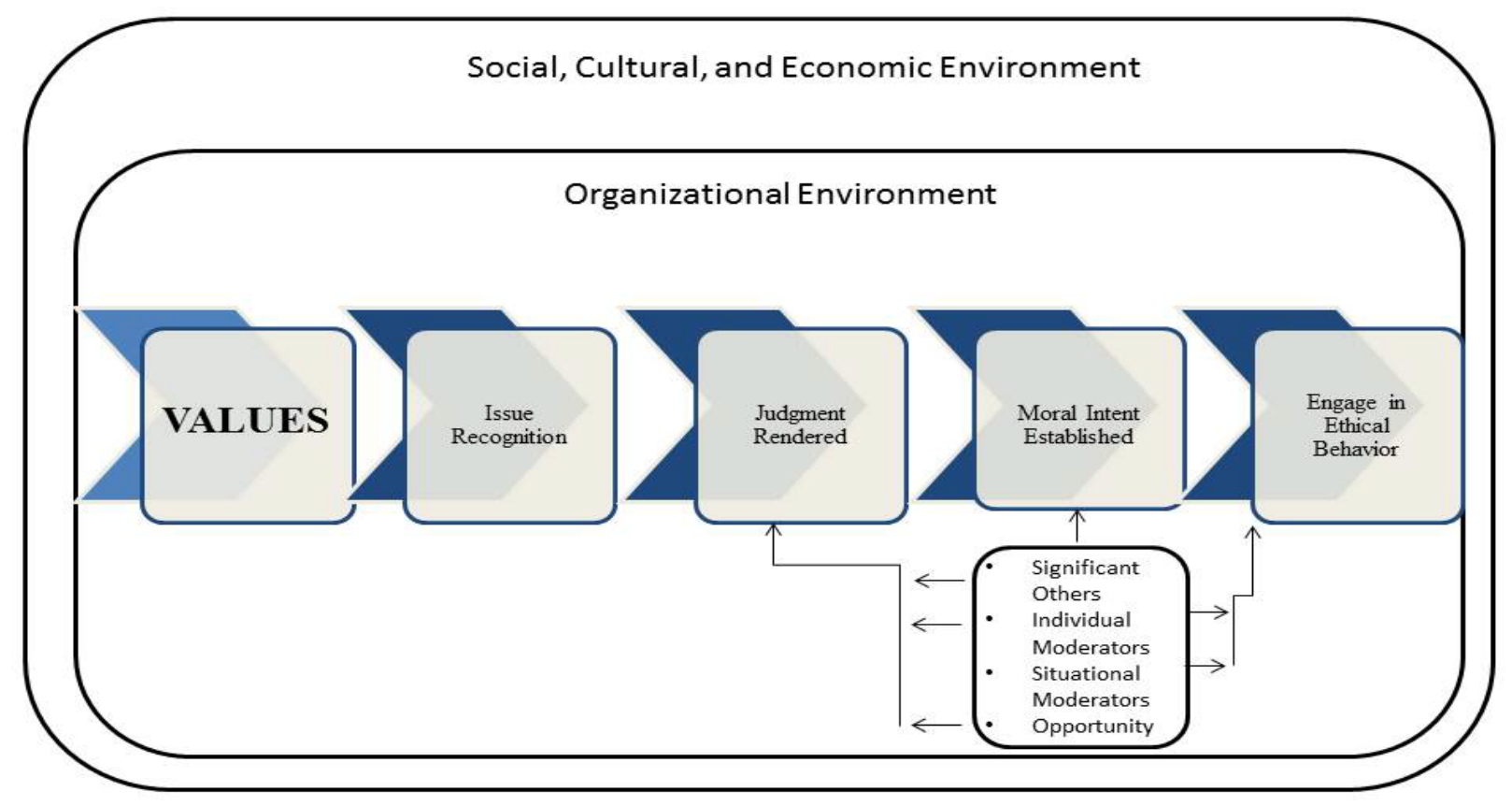

Figure 2. Repositioning values in the synthesis of ethical decision making adapted from Jones (1991)

The term "value set" comes into play as individuals tend to value multiple virtues, and at times these normative values conflict. Organizations and individuals hold their values in two ways. There are articulated values, such as mission statements valuing diversity and inclusion. There are also values in action, wherein values are revealed through the results of decision making processes. In economics, this would be called revealed preferences (Quah, Nishimura, \& Ok, 2015; Samuelson, 1948). Using the mission statement example again, articulations of diversity as a value notwithstanding, in practice enrollment and hiring trends reveal preferences for other priorities 
(e.g., perceptions of institutional prestige, cronyism) (Ahmed, 2007; Chun \& Evans, 2008; Goedegebuure, Coates, van der Lee, \& Meek, 2009; Rothman, Kelly-Woessner, \& Woessner, 2011; Thornton et al., 2010). The VIA tool allows critical reflection to enable congruence between articulated and revealed value preferences.

\section{Values}

Our system of values is so much a part of us we cannot separate it from ourselves. It becomes the navigating system that guides us. It establishes the priorities in our lives and judges what we will accept or reject. (Maxwell, 1993, p. 36)

Values are integral to how we perceive the world. This is why providing a means for leaders to make ethical decisions is important. The values that a leader holds and the moral system from which he or she operates "defines and shapes the change process, and takes actions to make his or her vision a reality" (Vogel, 2012, p. 1). How we see the world, our world view, in turn shapes how we perceive or frame issues. And by defining an issue in a particular way, we open the door to solution sets which match the issue as framed (Bollman \& Gallos, 2011). So it is important before we go forward to consider some of the values we hold dear in higher education.

Rather than thinking of values as individual characteristics (virtues such as courage, temperance, wisdom, humility, and optimism (Johnson, 2015; Keenan, 2015)), we are framing values as policy goals, justifications for decision making, and potential evaluative benchmarks for measuring effective leadership (Stone, 2002). The oft competing values of equity, efficiency, security, liberty, and justice are held in common across democratic spaces. Yet it is in the interpretation of each and permutations of prioritizations wherein individuals differ. These are presented in the VIA Model in Figure 3. Values can also shape how one perceives issues, a consideration to be addressed in future work.

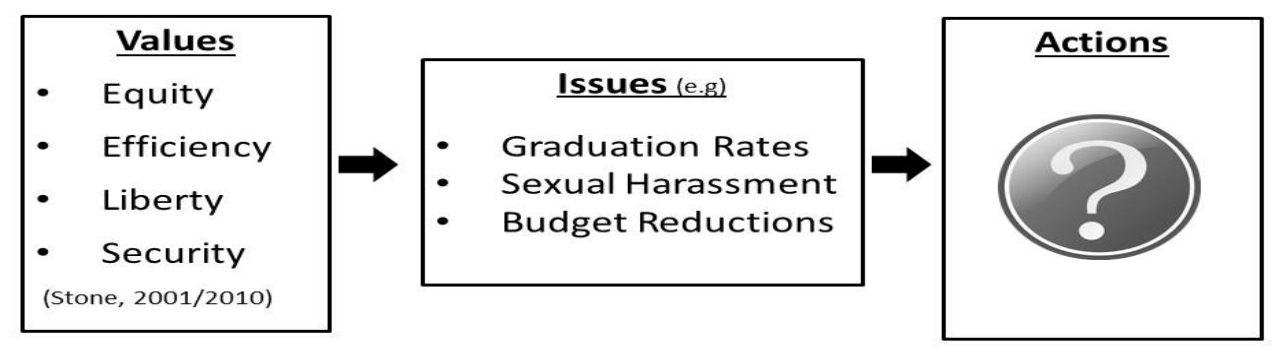

Figure 3. The VIA model for ethical decision making

\section{Equity}

Equity relates to the distribution of fairness, i.e., whether parties to a conflict are receiving a fair share of resources, time to be heard, or opportunities to participate within a decision making process (Young, 1990). Equality is one specific type of equity - equal distribution. However, sometimes in treating people equally, we are actually treating them differently because of their differences in knowledge, skills, and vulnerabilities (Minnow, 1991). Equity can take the form of equal individual opportunity (formal equality), equal group opportunities (substantive equality), differentiations by level or rank (vertical equity), maintaining equity within rank (horizontal equity), equity by way of how one values the resource being distributed, equity by way of probability (chance or lottery), merit or competition, and the list goes on (Stone, 2002).

The implied nature of equity refers to the notion that everyone should have access to education and have their educational needs adequately met in a manner that allows them to thrive and func- 
tion to their best ability. Achieving this is dependent on many factors with various causes that directly impact the education of college and university students. Access to education and financing are broad segments that disadvantaged students require to improve their education and education outcomes. Expanding equity to these students would allow them to benefit from educational resources that are often withheld or not easily accessed. Here equity would entail increasing access to educational opportunities for disadvantaged students. A direct application of the VIA model for equity would result in addressing the obstacles that these students face in attempting to attain the full potential of higher education.

The differentiation of education levels between disadvantaged students and those who are able to obtain a college or university degree in the United States signifies an importance in contending for equity in education. Systematic inequalities place these students in the position of not having the means to achieve the wellbeing that is afforded to those who are able to pursue higher education. Many of the educational inequities that disadvantaged students face are engrained into the socioeconomic structures that have operated in the United States for years (Braveman \& Gruskin, 2003). While the cause for these inequities originated outside of the higher education's parameters, students are impacted by them from college predisposition, access and continued enrollment, to and through academic and social developmental processes on campus, to graduation and even some opportunities post-graduation. While students are in under our influence, at the college or university, decisions can be made to proactively act to support their fullest development or allow them to compete as anonymous others on an uneven playing field.

Within a space of limited resources, how one conceives of equity for both input into decision making and resource allocations determines who is privileged within a distribution strategy. Taking the example of financial aid, we can gear support towards those who deserve more aid based on their previous academic accomplishments, a merit approach to equity. We often measure these through performance on college examination scores. However, we have known for decades that performance on college examination scores best predicts one's socioeconomic conditions, access to educational experiences, and better opportunities to learn those matters tested in the exams (National Scholarship Service and Fund for Negro Students [NSSFNS], 1957; Zwick \& Himelfarb, 2011). What if, rather than rewarding absolute scores, we measured gain scores, how much an individual improves over time. Would that too be considered merit? A student who already performs strongly has a smaller range in which their performance can improve. But students at the lower end of the distribution have greater opportunities for improvement. Is this equitable? Is this fair? Who decides and how do we as a society tend to explore questions like these?

\section{Efficiency}

Efficiency can be defined as a ratio between inputs and outputs. It allows us to obtain more of what we want per unit of cost (Stone, 2002). It is less about what we do than how we do it. Arguably, it is a secondary order value; however, in a climate of increasing accountability in higher education, efficiency seems valued as a virtue within itself. The question then becomes one of costs. A globally espoused goal of increasing the number of college graduates can readily be met by passing out diplomas to all drivers crossing the Delaware Bridge. But meeting this goal this way, is it efficacious in the long run? Do we really want more college graduates, or do we want an enhanced workforce and citizenry (OECD, 2015a)? Efficiency is only as valuable as the underlying ends. Another way to think about it is to consider efficiency for what purpose?

Presumptively we can increase the number of college graduates by increasing access to higher education. While there are many aspects of the college experience impinging on graduation post initial enrollment, the logic generally stands that more people in means more people out. However, as was found during higher education desegregation in the United States during the 1960s and 1970s, adding more students while maintaining a disjuncture between students of color and uni- 
versity leadership (including and especially faculty) in academic, social and developmental expectations, does not translate efficiently to higher graduation rates. Access increased. Enrollments increased, but concomitantly graduation rates did not. In this case, to become more efficient, higher education institutions had to think more about matters of equity (Peterson et al., 1978). Efficiency is a necessary consideration, especially given global reductions in public aid for higher education and a shifting of the costs of higher education from society to individuals (OECD, 2015b). However, as was the case in the desegregation era, efficiency based approaches often are not enough to effect long term strategic goals.

\section{Security}

The value of security invokes a notion of existentialism. Maslow $(1954 ; 2013)$ postulated that for individuals a baseline of security is needed in food, water, physical safety, and shelter. Before an individual can grow towards a path of self-actualization, institutions, organizations, units, and programs within academe need security in resource allocations and other supports in order to be productive. The dimensions between needs and wants are often blurred and include tensions between real (minimal survival) versus symbolic (prestige), relative (within group perspective versus absolute needs (outside group perspective), direct (needed for own sake) versus instrumental (needed for another purpose), future (safety) versus present day rewards, objective versus relational (Stone, 2002).

Matters of security on campus can be examined at multiple levels. For example, food insecurity and domestic violence are of increasing concern at the student level (Hughes, Serebryanikova, Donaldson, \& Leveritt, 2011; Rondeau, 2007). Education becomes a second order issue in relation to basic security needs. At the organizational level, the complexities of the business of higher education combined with uncertain financial markets contribute to volatility in academe (Bollman \& Gallos, 2011). Initiatives such as Tennessee's first two years free, community college for all, threaten programs and faculty at the four year level, as the first and second year college experience shift to the community college sector (Mangan, 2015; Sutton \& Hope, 2015). A perverse incentive of community college performance funding, state funding concomitant with outcomes such as graduation and transfer rates or grade point averages, are increasing enrollments of traditional students in community colleges and marginalization of the most marginalized, populations community colleges traditionally served (Levin, 2014). In times of scarcity, does a campus elect to hold one more section of developmental education to serve another set of students unlikely to attain a degree, or host a $2+2$ program, partnerships between the community college and a university, transfers for which they will be rewarded? Here security interests are challenged by notions of equity, positive liberty, and social justice, the latter two discussed below.

Finally, considerations of safety need to consider the physical integrity of campus grounds. A growing number of states allow guns on campus (Armed Campuses, 2013). In U.S. public institutions, how to balance campus safety concerns with individual rights to own and possess weapons? This question is particularly poignant given the growing number of students identified with mental health concerns. What about marginalized student populations? Do we hold face to face classes when a marginalized population is targeted for violence (Miller, 2015; Romano \& Alexander, 2015)? When violence is perpetrated on campus, how do we search for perpetrators without further destabilizing the security of innocent others (Smith, Yosso, \& Solórzano, 2007)?

\section{Liberty}

Liberty in its most base form is the freedom of conscience and thought or the ability to exercise choice (Stone, 2002). Some have argued that an extension of this basic foundation of liberty should be extended into various areas, like education. Negative liberty denotes the role of a government or other policy actor in preserving the space for individual action by not interfering, ex- 
cept for at the limits of one's liberty - the point at which the exercise of liberty by one harms or interferes with the liberties of another. By definition, this limitation inhibits liberty, and as such, national slogans notwithstanding, liberty is not without constraints. In fact, the logical outcome of purely liberty based governance is anarchy as each individual one governs according to his or her interests or pleasures. Liberty at an extreme inhibits collective action, opportunities for individuals to collectively pursue commonly held needs, wants, and interests. In the higher education sphere, we can give students liberty to select whatever courses they would like to take. However, faculty determine courses sequences which together compose a degree program. Taking the right number of courses does not equate with degree completion, if an individual fails to take requisite courses within the program of study. Where does that leave an individual with the requisite number of credits to graduate, but no program of study? Negative liberty needs boundaries, and colleges and universities are poised to advise students academically, even if it intrudes on their liberty.

Positive liberty involves the ability of individuals to be free to participate. For example, in the case of remedial education, successfully completing developmental coursework in math or language arts can enable someone to engage college level curricula. Without this assistance they are not able to engage the coursework. This is an example of a positive liberty, an intervention designed to help an individual participate. Another example is that of need-based financial aid. The benefit of both types of actions is that they help individuals surmount college participation barriers, thereby reducing talent loss. By supporting the capacity of individuals to participate in higher education global workforce and citizenry goals can be met (OECD, 2015a).

\section{Justice}

The simple approach to justice - to give to each and every one their due - like the simplistic approaches to each of the prior values is indeterminate when confronted with an actual issue (Raphael, 2001; Spooner, 1882). The question of who counts - as a citizen or member - regards the first part of this ancient mantra (Young, 1990). The second question regards what each is due. Two approaches predominate understandings of justice. Liberty based justice, a justice in holdings (what one owns), is advanced by Nozick (1974) in Anarchy, State and Reason. According to Nozick (1974, p. 149), holdings, what one owns or possesses, are just if they meet 1 of the following 2 criteria:

1. The acquisition is just (this usually involves some form of labor) or

2. The transfer is just (this regards gifts).

Here justice is strictly conceptualized as process oriented, without regard to outcomes. In other words, Nozick is arguing for a system that does not redistribute the additional resources gained through practice or income, but that the system ensures the appropriation of the resources in a just manner. Regardless of how an individual fares, so long as the transaction is fair then the process is just. For example, by Nozick's logic it is just for institutions which benefited from the slave trade to retain those benefits. As institutions are coming to terms with their sordid pasts, they are also grappling with how to make amends, how to make things right, suggesting an equity ethos beyond what Nozick espouses (Starr, 2015; Thomason, 2015; Wilder, 2013).

An equity approach to justice, justice as fairness, as advanced by Rawls (1971/1999) posits that a moral and fair conception of justice occurs when distributions in a society, at its inception, are equal and that each individual has a fair equality of opportunity to pursue his or her interests. Rawls offers a complex combination of liberty, reward, and equity. All members of Rawls' society are assumed to be rational beings who are mutually indifferent and do not suffer from envy, and the collective goal of these rational beings is to form a society that is set to maximize the interest of rights, liberty, opportunity, power, and income (Rawls, 1971/1999). It is not the case that 
distributions would remain equal, that individuals would work and exchange with each other in ways that make them better off, but also assuring that no individual succumbs to "the worst eventualities" (Rawls, 1971/1999, p. 154). Here justice is conceptualized as both process oriented and outcome regarding. Here, we do care that individuals who are disadvantaged are cared for; therefore, even if the transactional process seems fair on its face, net social benefits matter. We would question the transaction if it made individuals significantly worse off.

Often when we speak of justice in the higher education context, we actually speak of social justice. Yet, for as much as we talk about social justice, there is little within our field seeking to define what social justice is within the higher education context (Levin, 2014). Rendón (2014, p. 10) advances social justice as critical consciousness, an awareness of socioeconomic inequity and action taken "to transform entrenched institutional structures to ensure that people from all social group memberships have equal access to resources and opportunities." By this definition social justice implicates equity, efficiency, security, and liberty and prioritizes definitions of equity that raise the ability of the underserved to participate (positive liberty). As a socially just society is more stable, over time it is more secure (Rawls, 1971/1999). But it may mean that we are less efficient in the short term, looking beyond surface level student characteristics to decipher and support hidden talents.

\section{Using the VIA Model}

In this section we take values from above - equity, efficiency, security, liberty and justice - and test them against common issues in academe using the VIA framework: increasing graduation rates, sexual assault policies, and budget reductions. We propose several solutions to each, considering the merits of each action through the VIA frame. Please note that these are thought experiments, subject to interpretation and debate, and are not assertions of fact. Within the context of classroom instruction students can consult the research literature and decipher implications based on empirical knowledge. Students can also become attuned to where empiricism falls short and where institutional context influences the applicability of literature suggested recommendations. Also note, the discussion here is cursory. There is much more that could be explored, even debated within a classroom setting.

\section{Issue 1: Increasing the number of college graduates}

A globally shared goal is that of increasing the number of college educated individuals in order to enhance the workforce and citizenry. We've already examined this issue as a matter of efficiency. If efficiency is our primary value, then we can increase graduation rates by lowering standards. This could be done in a myriad of ways, more rational than doling degrees on a highway. Addressing the graduation rates of students already in college, some institutions find the number of credits required to be a barrier. This may be a true barrier if the number of courses required within a particular division or institution wide exceeds those of peer institutions. As a matter of efficiency, a curriculum review to examine where course content can be merged or cut may be in order. Another situation lowering standards solves is when students take a number of remedial courses which do not count for general education credit and take a year or longer to complete their degrees. For these students, running out of financial aid can be a major concern and barrier to graduation. However, in this case, is lowering standards an optimal solution? If remediation is the concern, lowering standards by cutting the number of credits required would most likely occur in the general education curriculum. Efficient? Yes. But, what about concerns for equity, liberty, security, and social justice? See Figure 4. By cutting courses this way there is an inequitable distribution of course taking and perhaps also learning between current and future graduates. In the short term, the liberty interests of those immediately impacted by the change in standards would be improved. They would be out of college and onto the job market more quickly. Howev- 
er, the long term liberty interests of all graduates may be negatively impacted. General education curriculum is most aligned with the liberal arts, which is associated with critical thinking development. Critical thinking is a skill is in demand by employers across private and public sectors. What if the new graduates become less adept at critical thinking? If the institution develops a reputation for lowered standards, that has implications on the liberty interests of all graduates as new graduates seek their first jobs and more seasoned alumni vie on the job market.

As a matter of social justice, students graduating under lowered standards, especially those students coming from backgrounds of modest means, are not helped long term as they have a degree, but perhaps not the critical thinking abilities, making it more challenging and giving them a greater learning curve when entering their career. As a matter of security, a degree from an institution of weakened reputation may render graduates less competitive in the job market, less able to make use of the education obtained. Jobless college graduates are insecure, struggling to meet basic human needs (unless they return home, which is an option for some but not all). For the institution, a diminished reputation may be correlated with lowered enrollments (as was experienced by the University of Phoenix). Decreased enrollments implicate decreased funding, which undermines the security of the institution.

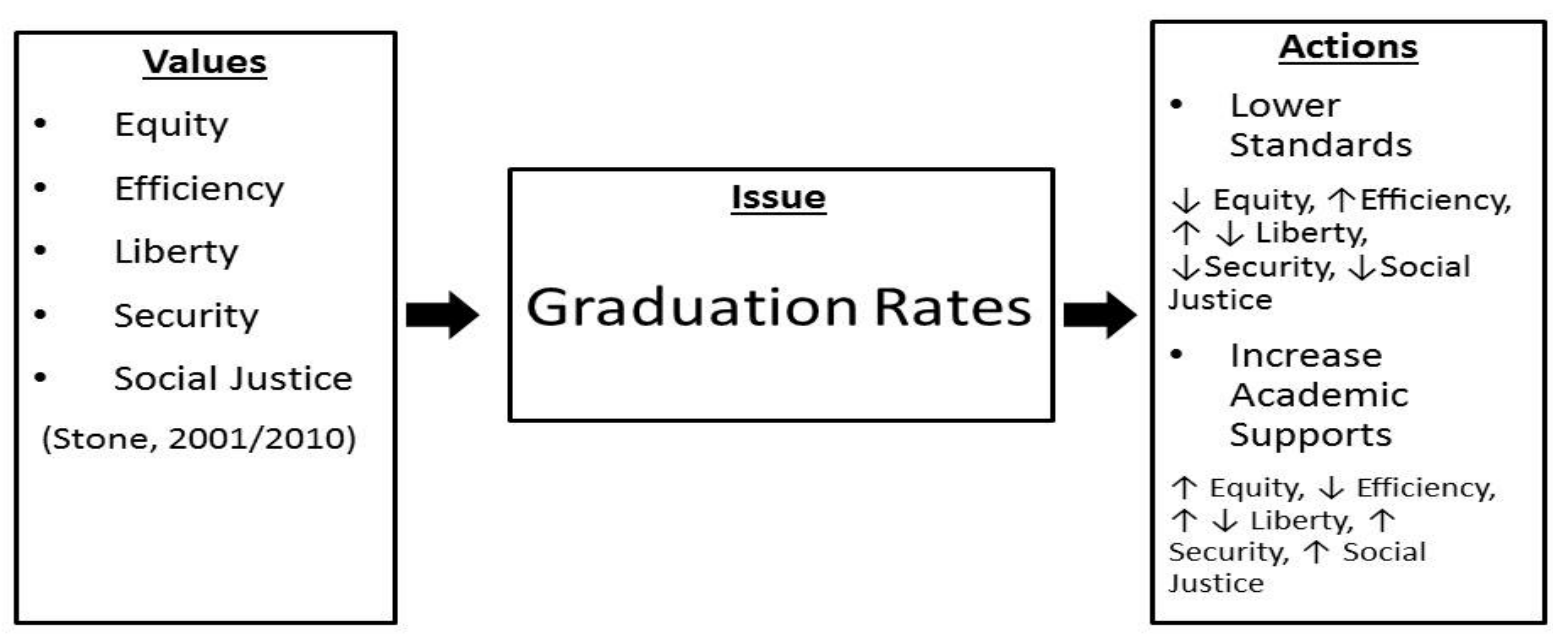

Figure 4. Graduation rates analysis through the VIA model

What if rather than lowering standards an institution sought to increase academic supports for struggling students? In the short term there may be inefficiencies generated through the address of structural concerns: developing or expanding tutorial services, writing centers, peer mentoring, or academic advising. There are also budgetary implications, and in an age of decreasing public support for higher education globally, leadership would be needed to prioritize expanding academic supports over competing enterprises such as green initiatives on campus, incubation support for revenue generating initiatives, or programming to recruit and retain honors students. It is not that these initiatives are mutually exclusive, but as scarcity is real, one must make hard choices. Long term academic supports enhance equity and social justice, foster positive liberty, and as these students become alumni, taking their place in the global citizenry, they can contribute towards a more secure society.

\section{Issue 2: Sexual assault on campus}

In the case of sexual assault, the liberty or freedom to do what one wants to do is prohibited by the physical and psychic harm inflicted on another. However, as perceptions of interpersonal rela- 
tions are culturally influenced, it can be challenging to transcend local norms of acceptable behavior. Yet on campus, this is the charge. In a 2011 "Dear Colleague" letter to educational institutions in the United States, including colleges and universities, the Office of Civil Rights asserts that institutions have an obligation to protect students and investigate incidents, whether occurring on or off campus (Ali, 2011). Therefore, regardless of off campus community norms, stereotypes of students and other campus actors as sexually loose or otherwise "deserving" of unwelcomed attention, institutions must develop policies and procedures to assist persons sexually harassed and educate the campus community on sexual violence. State and national policies may vary globally.

When faced with the challenge of addressing sexual assault, a campus may attempt to maintain the status quo, utilizing policies and procedures already in place (See Figure 5). In the wake of studies on the underreporting of sexual assault (Fisher, Cullen, \& Turner, 2000; Kilpatrick, Resnick, Ruggiero, Conoscenti, \& McCauley, 2007) and predatory behavior on the part of perpetrators (Abbey, Ross, McDuffie, \& McAuslan, 1996; Lisak \& Miller, 2002), can a campus afford to maintain the status quo? As a matter of equity, while it is the case that men can and are at times victimized, assault tends to be experienced more by women. There is also variance by LGBTQ status, with individuals in that spectrum being more likely to be sexually assaulted. As a matter of efficiency, doing nothing could expose an institution to lawsuits. In the United States, according to the Office of Civil Rights, a singular act is enough to create a hostile environment on campus and doing nothing would be failing to protect, failing to prevent in dereliction of policy guidance. Lawsuits are inherently inefficient, taking both fiscal and human resources, not to mention time and opportunity costs, resources that can be spent on more productive activities. As a matter of liberty, the status quo favors perpetrators but impinges on actual and potential victims. Individuals make choices, where to go and when as well as how to dress, based on perceived safety. Each of these decisions implicates liberty and security interests, constraints thereupon. There are also social justice considerations. Is maintaining the status quo socially just? Do status quo policies improve the status of those most greatly impacted by sexual assault?

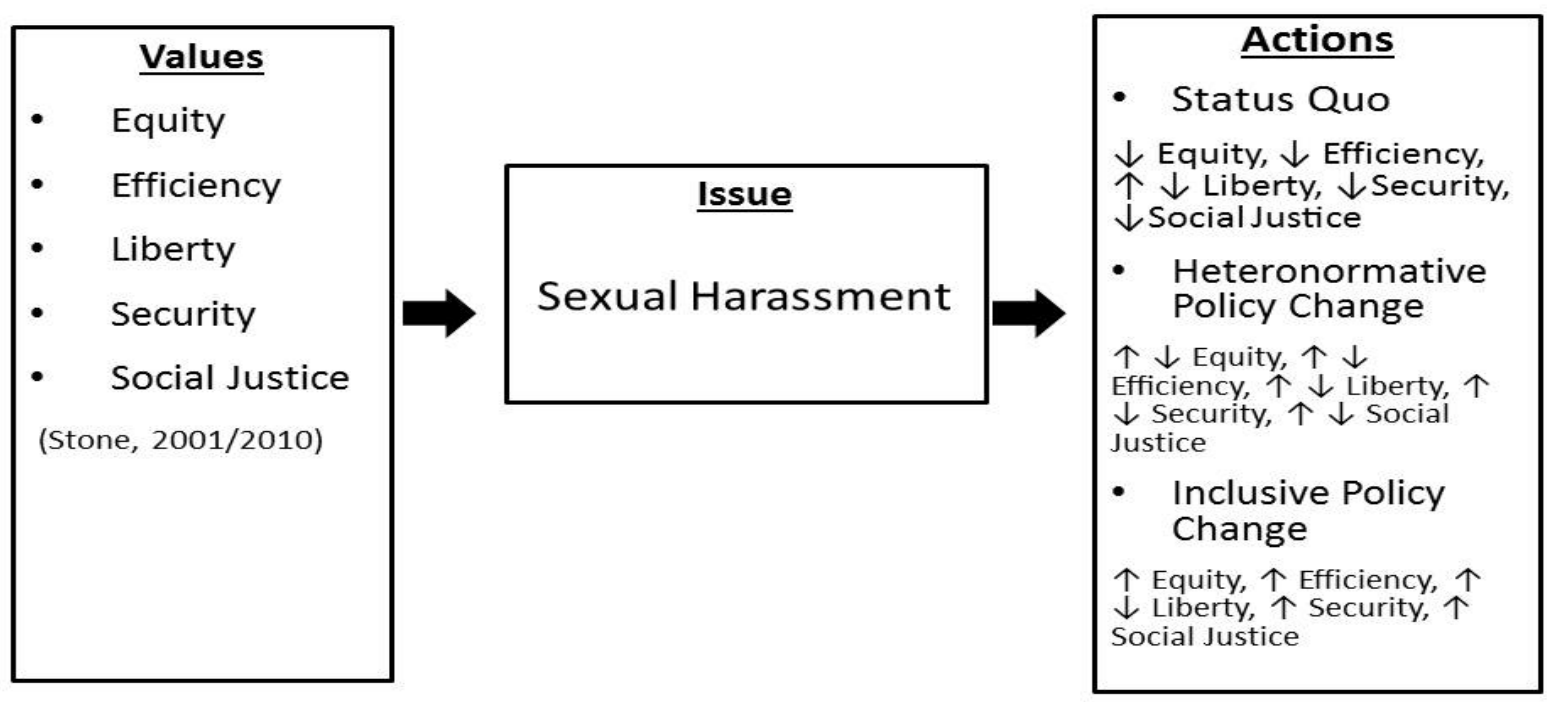

Figure 5. Sexual assault policy analysis through the VIA model

Most campuses in the United States have made policy changes based on the 2011 "Dear Colleague" letter. However, an ongoing concern in this area is whether policy changes are broad or flexible enough to encompass sexual assault in multiple forms. A significant limitation of policies in the 1980 s was that they tended to be heteronormative. This means that they only covered as- 
saults across gender lines and were silent on same-sex incidents. Another consideration is that of hierarchy. In the campus environment, policies tend to be clearer when assault is within rank student to student, faculty to faculty, staff to staff - or of a higher ranking individual to a lower ranking one (e.g., faculty to student). However, what are the policies/ procedures when a person deemed of lesser power, a student for example, perpetrates assault against an individual deemed to have greater power, say a faculty member? Policy changes in these veins increase equity for some, providing greater protection for women harassed by men (and vice versa), but persons subjected to same sex assault are treated unequally. This increases security, the sense of security in one's person, as well as liberty interests. As a matter of social justice, it does help raise the status of those with lesser power; however, heteronormative policies fall short with LGBTQ communities. In addition, these policies tend to exclude situations where power dynamics are inverted, someone of lesser power violating another of higher authority.

Ideally, a policy should be inclusive, to encompass a wide range of scenarios, so as to provide the greatest amount of protection. Policies should be written so that footballers or others thought macho, for example, could be attended if assaulted and have an avenue of redress whether harassed same sex or across gender lines. Whether or not we value social justice and for whom we value social justice determines whether we frame the issue as such. If we do not perceive the issue in that dimension, we may perceive the issue of sexual assault as a binary one between men and women, and power dynamics as unidimensional. An inclusive policy solution must address interactions between sexes and include same sex and inverted power dynamics. Inclusive policies support our values as a matter of equity, liberty, security, and social justice, only constraining the liberty (and perhaps security interests) as those who violate others. And that is socially just.

\section{Issue 3: Budget reductions}

A third issue to consider is that of budget reductions. In the wake of the financial crisis of 2008, many higher education institutions deliberated on how and where to make cuts to their budgets in order to preserve their ongoing viability. One approach is that of across the board cuts, reclaiming a certain flat percentage of allocations from each unit (See Figure 6). While equal in the sense that each unit would lose the same fraction of their budget, across the board cuts like flat taxes are necessarily regressive, disproportionately harming those with fewer resources. While $3 \%$ of a larger budget yields more, the value of 3\% to a smaller unit is greater: the difference between $3 \%$ of a $\$ 30,000$ as compared to a $\$ 300,000$ budget. Implementing the cut is easy, efficient in the sense that all one needs to know is what is a unit's budget and apply the same flat cut to each unit. Long term efficiency in the form of productivity losses may occur and will be borne disproportionately by smaller budgeted units. As finances provide liberty, the ability to carry out various programming and operations, across the board cuts are liberty inhibitive. These cuts can also reduce security, especially for areas with smaller budgets. They may be cut to the point where they are unable to carry out their functions. The unit may be dissolved or cobbled with other units to remain active, even at a diminished capacity. As a matter of social justice, one would need to consider the areas wherein those smaller budgets lie (e.g., engineering versus philosophy) and the impact of those cuts on insular populations impacted by those cuts.

One way to better distribute cuts is by some means of program prioritization. Through program prioritization processes, leaders can reflect on what functions are most important to institutional survival, a matter of security - perhaps both short and long term. These processes are frustrating under the best of circumstances but, under the pressure to reduce expenditures, units put forward their best case for why they deserve a greater share. Sympatico units are thrust into a competition for resources and for better or worse dissolve academic consensus - the freedom to live and let live (Dickeson, 2010). We offer two scenarios of program prioritization: efficiency based and mission based. 
In an efficiency based prioritization schema, the ultimate goal is to retain the biggest bang for the buck. Considerations are of where the university is getting the greatest returns on invested dollars. Units with larger enrollments, higher graduation rates, job placements, and extramural funding tend to be rewarded in this process. Wherein fits liberal arts? It may be efficient to cut international languages, philosophy, religion, women's studies, ethnic studies, and even public administration (after all those governmental officials got us into this mess - or was it business? But we could never cut there. They bring in the money!). What kinds of cuts are needed to secure the future of higher education without sacrificing core products such as the production of critical thinkers and well-rounded individuals? That is a security matter as it cuts to the core of what makes higher education higher as opposed to vocational education. Can we obtain social justice more broadly by cutting way those programs and departments best equipped to lead those types of inquiries? See the conversation on efficiency and lowering standards above.

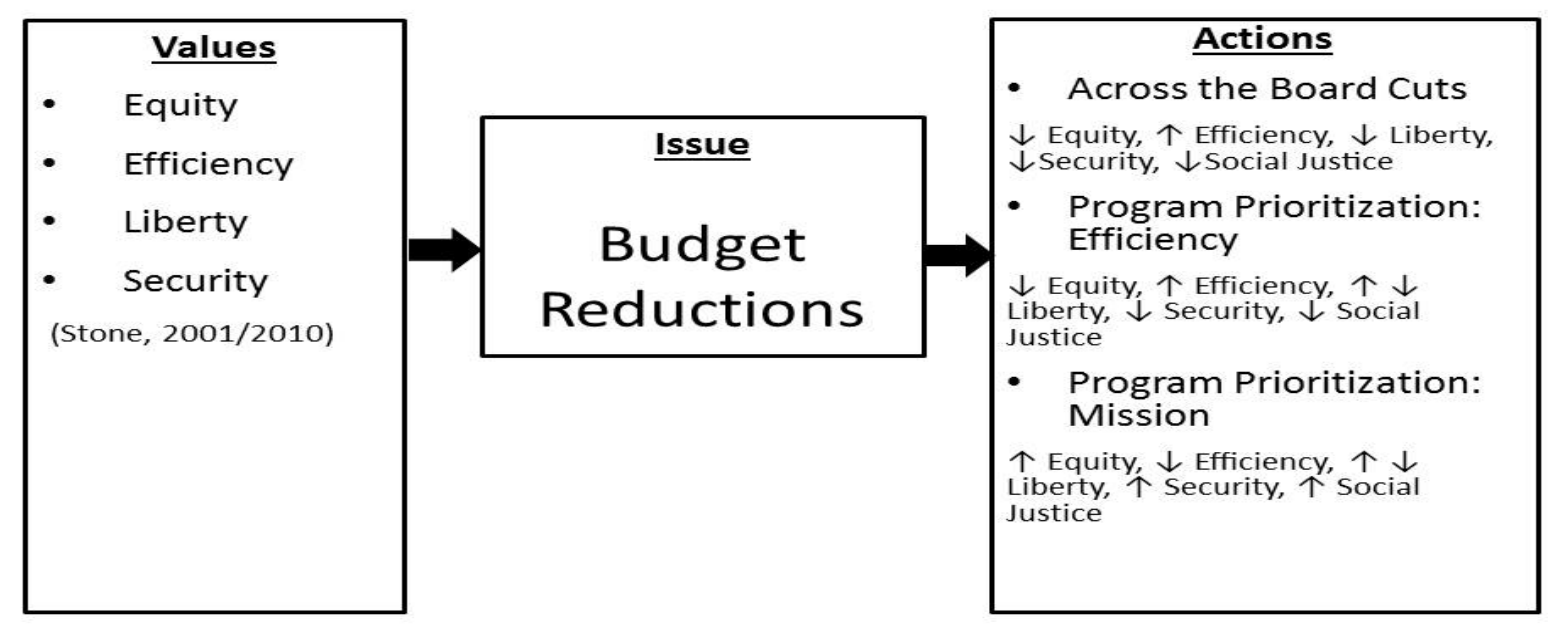

Figure 6. Budget reduction analysis through the VIA model

An alternative to the efficiency based strategy is a mission focused one. While competition is still a core component of the program prioritization process, units can align their goals to the institutional mission, redistributing resources from units at the periphery of those missions to those more central. In fact, as a matter of efficiency, this is a process that arguably should be engaged in more regularly and in the absence of crisis (Nielsen, 2013). Regular attention to program prioritization by mission reduces programmatic sprawl, protecting resources for an institution's core and thereby increasing security at that core. It is constricting of liberty (especially in areas more remote from the institutional mission), but potentially such a process would yield more equity and social justice goals supporting the diversity, inclusion, and outreach provisions embedded in many statements.

These three issues are but a sample of robust questions for discussions within the context of a course on higher education ethics, ethics discussions in related coursework, or as a matter of personal reflection. How does an individual tend to frame each of these issues? Through which value/ set thereof? How does an individual prioritize competing values? What are the resultant actions/ recommendations for actions based on that frame? In reframing, how does the solution change? What about the issue itself, does it change when considering a different values frame? In evaluating competing solutions, how does an individual take sides? 


\section{Conclusion}

Ethics and ethical decision making is important as a higher education leader's decisions have long range consequences for all stake holders, and the quality of decisions made impinge on institutional success. The VIA Model is a multifaceted approach based on value assessment and applied ethics designed to develop reflective practice among higher education leaders. By critically reflecting on one's values, individually and collectively within value sets, individuals and organizations can assess their value prioritizations. Therefore, when faced with issues they are better able to meet ethical challenges with actions more congruent to their values. A final example from the headlines is used to illustrate. Teresa Sullivan of the University of Virginia was faced with a Rolling Stone article surfacing allegations of gang rape by fraternity members followed up by an Office of Civil Rights investigation into a culture supporting sexual violence, evinced by a series of incidents garnering notoriety. Instead of hoisting a public relations campaign to combat allegations, she threw open the doors of the university to external inquiry and organized internal activities among students, faculty, and administration to devise strategies to combat sexual violence on campus (Sullivan, 2014). While the ridicule and public acrimony was challenging (Carmon, 2014; Steinhauer \& Pérez-Peña, 2014), a result of this difficult course of action is that the University of Virginia is the only institution in the U.S. to have a federally approved sexual assault and safety policy (deBruyn, 2015). The decision to pursue this course of action came down to values. In a letter to parents, soon after the publication of the article, Sullivan and Lampkin (2014, para. 2) assert, "our first priority in this immediate situation is to keep our students safe." An articulation of values helped reshape the issue wherein the university deprioritized the reputational safety of the institution and privileged members of the community, to better reflect decisions to support the safety at all. This example of VIA in action, even if retroactively fit, harbingers possibilities for this tool in higher education leadership development.

\section{Implications for Teaching, Learning, and Leadership Practice}

According to Bollman and Gallos (2011, p. 8), the complexities of leading higher education institutions in the modern era "point to the need for understanding and for solid preparation in order tackle the complexity and to strengthen leadership skills and resolve." A significant part of this preparation can and perhaps should include the development of an ethical reflective practice. We propose the VIA model as a tool for developing this practice. Examples given herein demonstrate the use of VIA to ask probing questions, to have emergent leaders reflect on their values and how their values shape the way they see issues as well as the solution sets to which the ascribe. The VIA model can also be applied to case studies, whether identified in the field or provided by the instructor. These methods, among others, encourage critical thinking, critical reflective practice, as well as foster student learning through Socratic inquiry and problem based learning techniques. This model can also be taken from the classroom into practice to encourage ongoing ethical decision making, whatever the professional codes governing the institution may be.

\section{Acknowledgement}

Thanks to Nurah Aldayel, Elizabeth Coghill, Heather Gray, and Whitney Morris for their contributions to this project. Special thanks to Les Goodchild for his guidance and support. You will be missed. 


\section{References}

Abbey A., Ross L. T., McDuffie D., \& McAuslan, P. (1996). Alcohol, misperception, and sexual assault: How and why are they linked? In D. M. Buss \& M. Malamuth (Eds.). Sex, power, conflict: Evolutionary and feminist perspectives (pp. 138-161). New York: Oxford University Press.

Ahmed, S. (2007). 'You end up doing the document rather than doing the doing': Diversity, race equality and the politics of documentation. Ethnic and Racial Studies, 30(4), 590-609.

Ali, R. (2011). Dear colleague letter. U.S. Department of Education, Office of Civil Rights, Retrieved from http://www2.ed.gov/about/offices/list/ocr/letters/colleague-201104_pg19.html

Altbach, P. G. (2001). Academic freedom: International realities and challenges. Higher Education, 41(1), 205-219.

Anderson, S., Lujan, L., \& Hegeman, D. (2009). Prepared for challenges: The importance of a professional and institutional ethical identity. New Directions for Community Colleges, Winter(148), 17-29.

Armed Campuses. (2013). Guns on campus' laws for public colleges and universities: A guide for parents. Retrieved from http://www.armedcampuses.org/

Association of University Professors (AAUP). (1966/2009). Statement on professional ethics. Retrieved from http://www.aaup.org/report/statement-professional-ethics

Aziz, S., Mullins, M., Balzer, W., Grauer, E., Burnfield, J., Lodato, M., \& Cohen-Powless, M. (2005). Understanding the training needs of department chairs. Studies in Higher Education, 30(5), 571-593.

Beauchamp, T. L., \& Childress, J. F. (2001). Principles of biomedical ethics. New York, N.Y: Oxford University Press.

Bernhardt, L. M. (2014). Theory and practice: A primer for students of applied ethics. CreateSpace Independent Publishing Platform.

Bollman, L. G. \& Gallos, J. V. (2011). Reframing academic leadership. San Francisco: Jossey-Bass.

Braveman, P., \& Gruskin, S. (2003). Defining equity in health. Journal of Epidemiology and Community Health, 57, 254-258.

Carmon, I. (2014). UVA president on rape controversy: “We will lead." MSNBC.com, Retrieved from http://www.msnbc.com/msnbc/uva-president-rape-controversy-we-will-lead

Chun, E. B., \& Evans, A. (2008). Demythologizing diversity in higher education. Diverse Issues in Higher Education, 25(2), 32.

Cohen, J. S. (2015). University of Illinois OKs $\$ 875,000$ settlement to end Steven Salaita dispute. The Chicago Tribune. Retrieved from http://www.chicagotribune.com/news/local/breaking/ct-steven-salaitasettlement-met-20151112-story.html

Consent Decree. (2012). Binding consent decree imposed by the National Collegiate Athletic Association and accepted by the Pennsylvania State University. Retrieved from http://s3.amazonaws.com/ncaa/files/20120723/21207236PDF.pdf

Council for Industry and Higher Education [CIHE] (Great Britain), \& Institute of Business Ethics. (2005). Ethics matters: Managing ethical issues in higher education. London: CIHE and Brunel University.

deBruyn, A. P. (2015). U. Va. moves forward with sexual assault and safety enhancements following conclusion of OCR compliance review. Retrieved from https://news.virginia.edu/content/uva-movesforward-sexual-assault-and-safety-enhancements-following-conclusion-ocr-compliance

Deigh, J. (2010). An introduction to ethics. New York: Cambridge University Press.

Des Garennes, C. (2014). Salaita prompted donors' fury. The News-Gazette. Retrieved from http://www.news-gazette.com/news/local/2014-09-02/salaita-prompted-donors-fury.html

Dickeson, R. (2010). Prioritizing academic programs and services: Reallocating resources to achieve strategic balance, revised and updated. San Francisco, CA.: Jossey-Bass. 
Teaching Ethics using the Values-Issues-Action (VIA) Model

Dubinsky, A. J., \& Loken, B. (1989). Analyzing ethical decision making in marketing. Journal of Business Research, 19(2), 83-107.

ESPN.com. (2012). Penn State sanctions: $\$ 60 M$, bowl ban. Retrieved from http://espn.go.com/collegefootball/story/_id/8191027/penn-state-nittany-lions-hit-60-million-fine-4-year-bowl-ban-wins-dating$\underline{1998}$

ESPN.com. (2015). Joe Paterno is now winningest coach. Retrieved from http://espn.go.com/collegefootball/story/_id/12179571/joe-paterno-111-wins-were-vacated-restored

Ferrell, O. C., \& Gresham, L. G. (1985). A contingency framework for understanding ethical decision making in marketing. Journal of Marketing, 49(3), 87-96.

Fisher, B. S., Cullen, F. T., \& Turner, M. G. (2000). The sexual victimization of college women. U.S. Department of Justice: Washington, D.C..

Freeh Sporkin \& Sullivan LLP. (2012). Report of the special investigative counsel regarding the actions of the Pennsylvania State University related to the child sexual abuse committed by Gerald R. Sandusky (b.k.a. The Freeh Report). Retrieved from https://www.documentcloud.org/documents/396512-reportfinal-071212.html

Fullan, M., \& Scott, G. (2009). Turnaround leadership for higher education. San Francisco: Jossey-Bass.

Gallant, T. B., \& Klaichman, M. (2010). Academic ethics: A systems approach to understanding misconduct and empowering change in the academy. In T. B. Gallant (Ed.). Creating the ethical academy: A systems approach to understanding misconduct and empowering change in higher education (pp. 2744). New York: Routledge.

Gmelch, W. H., \& Miskin, V. D. (1993). Leadership skills for department chairs. San Francisco: JosseyBass.

Gmelch, W. H., \& Miskin, V. D. (2004). Chairing an academic department. Madison, WI: Atwood.

Goedegebuure, L., Coates, H., van der Lee, J., \& Meek, V. L. (2009). Diversity in Australian higher education: An empirical analysis. Australian Universities' Review, 51(2), 49-61.

Heyneyeman, S. P. (2010). The concern with corruption in higher education. In T. B.Gallant (Ed.), Creating the ethical academy: A systems approach to understanding misconduct and empowering change (pp. 13-26). New York: Routledge.

Heyneyeman, S. P. (2013). Higher education institutions: Why they matter and why corruption puts them at risk. In G. Sweeney, K. Despota, \& S. Linder (Eds.), Global corruption report: Education (pp. 101107). New York: Routledge.

Heyneyeman, S. P., Anderson, K. H., \& Nuraliyeva, N. (2008). The cost of corruption in higher education. Comparative Education Review, 52(1), 1-25.

Hughes, R., Serebryanikova, I., Donaldson, K., \& Leveritt, M. (2011). Student food insecurity: The skeleton in the university closet. Nutrition \& Dietetics, 68(1), 27-32.

Hunt, S. D. \& Vitell, S. (1986). A general theory of marketing ethics. Journal of Macromarketing, 6(1), 516.

Inclusive Illinois. (n.d.). Mission and vision. Retrieved from $\underline{\mathrm{http}: / / \text { inclusiveillinois.illinois.edu/mission.html }}$

International Association of Universities. (2014). Documents. Retrieved from http://www.iauaiu.net/content/documents-0

Johnson, C. E. (2015). Meeting the ethical challenges of leadership: Casting light or shadow. Thousand Oaks, CA: SAGE.

Jones, T. M. (1991). Ethical decision making by individuals in organizations: An issue-contingent model. Academy of Management Review, 16(2), 366-395. 
Kaplin, W. A., \& Lee, B. A. (2013). The law of higher education (5th ed). San Francisco, CA: Jossey-Bass.

Keenan, J. F. (2015. University ethics: How colleges can build and benefit from a culture of ethics. Lanham, MD: Rowman \& Littlefield.

Kilpatrick, D. G., Resnick, H. S., Ruggiero, K. J., Conoscenti, L. M., \& McCauley, J. (2007). Drug facilitated, incapacitated, and forcible rape: A national study. Charleston, SC: Medical University of South Carolina, National Crime Victims Research and Treatment Center.

Levin, J. S. (2014). Nontraditional students and community colleges: The conflict of justice and neoliberalism. New York: Palgrave MacMillan.

Lisak, D., \& Miller, P. (2002). Repeat rape and multiple offending among undetected rapists. Violence and Victims, 17(1), 73-84.

Mangan, K. (2015). Free community college jolts enrollments as questions persist for 4-year campuses. The Chronicle of Higher Education. Retrieved from http://chronicle.com/article/Free-Community-CollegeJolts/233109

Maslow, A. H. (1954). Motivation and personality. New York: Harper \& Brothers.

Maslow, A. H. (2013). A theory of human motivation. U.S.A.: Martino Fine Books.

Maxwell, J. (1993). Developing the leader within you. Nashville, TN: Thomas Nelson, Inc.

Miller, M. E. (2015). As death threats spread fear at Mizzou, professor asks students to defeat "bullies" and attend class. The Washington Post, Retrieved from https://www.washingtonpost.com/news/morning-

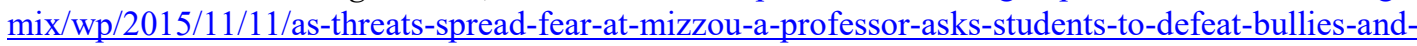
attend-class/

Meiners, R. E. (2004). Faculty towers: Tenure and the structure of higher education. Oakland, CA: The Independent Institute.

Minnow, M. (1991). Making all the difference: Inclusion, exclusion, and American law. Ithaca, NY: Cornell University Press.

National Scholarship Service and Fund for Negro Students (NSSFNS). (1957). Blueprint for talent searching: America's hidden manpower. Retrieved from ERIC database (ED020955).

Nielsen, L. (2013). Provost: Experiences, reflections and advice from a former "number two" on campus. Sterling, VA: Stylus.

Nozick, R. (1974). Anarchy, state, and utopia. New York, NY: Basic Books.

Olivas, M. A. (2006). The law and higher education: Cases and materials on colleges in court (3rd ed.). Durham, NC: Carolina Academic Press.

Organization for Economic Co-operation and Development (OECD). (2015a). Education indicators in focus. Retrieved from http://www.oecd.org/education/skills-beyondschool/EDIF\%2031\%20\%282015\%29--ENG--Final.pdf

Organization for Economic Co-operation and Development (OECD). (2015b). Access to education. In OECD Government at a glance 2015 (pp. 174-175). Paris: OECD Publishing.

Palmer, P. J. (2000). Let your life speak: Listening for the voice of vocation. Thousand Oaks, CA: SAGE.

Paterno, J. (2014). Paterno legacy: Enduring lessons from the life and death of my father. Chicago: Triumph Books LLC.

Peterson, M., Blackburn, R. T., Gamson, Z. F., Arce, C. H., Davenport, R. W., \& Mingle, J. R. (1978). Black students on white campuses: The impacts of increased black enrollments. Ann Arbor: Institute for Social Research, The University of Michigan.

Quah, J., Nishimura, H., \& Ok, E. A. (2015). A comprehensive approach to revealed preference theory (No. 752). University of Oxford, Department of Economics. 
Raphael, D. D. (2001). Concepts of justice. Oxford: Oxford University Press.

Rawls, J. (1971/1999). A theory of justice (Rev. ed.). Cambridge, MA: Belknap Press of Harvard University Press.

Reeves, D. (2010). Transforming professional development into student results. Alexandria, VA: Association for Supervision and Curriculum Development.

Rendón, L. I. (2014). Sentipensante (sensing/thinking) pedagogy: Educating for wholeness, social justice and liberation. Sterling, VA: Stylus.

Rest, J. R. (1986). Moral development: Advances in research and theory. New York: Praeger.

Rittel, H. W. J., \& Webber, M. M. (1973). Dilemmas in a general theory of planning. Policy Sciences, 4, 155-169.

Romano, A., \& Alexander, M. (2015). Missouri police arrest man after threats to hurt blacks. Reuters. Retrieved from http://www.reuters.com/article/2015/11/12/us-missouri-boycott

Rondeau, K. (2007). Hunger on campus: Understanding food insecurity in postsecondary students. Edmonton, $\mathrm{AB}$ : Alberta Centre for Active Living.

Rothman, S., Kelly-Woessner, A., \& Woessner, M. (2011). The still divided academy: How competing visions of power, politics, and diversity complicate the mission of higher education. Lanham, MD: Rowman \& Littlefield Publishers, Inc.

Salaita, S. (2015). Why I was fired. The Chronicle Review. Retrieved from http://louisproyect.org/2015/10/06/steven-salaita-why-i-was-fired/

Samuelson, P. A. (1948). Consumption theory in terms of revealed preference. Economica, 15(60), 243253.

Slaughter, S., \& Rhodes, G. (2004). Academic capitalism and the new economy: Markets, state, and higher education. Baltimore: The Johns Hopkins Press.

Smith, W. A., Yosso, T. J., \& Solórzano, D. G. (2007). Racial primes and Black misandry on historically White campuses: Toward critical race accountability in educational administration. Educational Administration Quarterly, 43(5), 559-585.

Spooner, L. (1882). Natural law, or the science of justice: A treatise on natural law, natural justice, natural rights, natural liberty, and natural society; showing that all legislation whatsoever is an absurdity, a usurpation, and a crime. Retrieved from http://praxeology.net/LS-NL-1.htm

Starr, A. (2015). Colleges and universities reconsider symbols tied to racism and slavery. National Public Radio. Retrieved from http://www.npr.org/sections/thetwo-way/2015/11/23/456807863/colleges-anduniversities-reconsider-symbols-tied-to-racism-and-slavery

Steinhauer, J., \& Pérez-Peña, R. (2014). University of Virginia’s image suffers after campus rape report. The New York Times. Retrieved from http://www.nytimes.com/2014/11/25/us/rocked-by-rape-reportuniversity-of-virginia-to-hold-special-meeting.html? $\mathrm{r}=1$

Stone, D. (2002). Policy paradox: The art of political decision making (revised ed.). New York: W. W. Norton \& Company.

Sullivan, T. A. (2014). An important message to the university community from President Sullivan. Retrieved from https://news.virginia.edu/content/important-university-virginia-messages-regardingsexual-assault\#sullivan\%20nov\%2019

Sullivan, T. A., \& Lampkin, P. M. (2014). Message to parents from President Teresa A. Sullivan and Vice President and Chief Student Affairs Officer Patricia M. Lampkin. Retrieved from https://news.virginia.edu/content/important-university-virginia-messages-regarding-sexualassault\#parents

Sutton, H., \& Hope, J. (2015), Learn 7 ways Tennessee community colleges doubled completion rates. Enrollment Management Report, 19(5), 1-5. 
Thomason, A. (2015). Students are protesting racism on college campuses. What are their demands? The Chronicle of Higher Education. Retrieved from http://chronicle.com/blogs/ticker/students-areprotesting-racism-on-college-campuses-what-are-their-demands/106721

Thornton, M., Bricheno, P., Iyer, P., Reid, I., Wankhede, G., \& Green, R. (2010). Diversity and social integration on higher education campuses in India and the UK: Student and staff perspectives. Research in Post-Compulsory Education, 15(2), 159-176,

Trevino, L. K. (1986). Ethical decision making in organizations: A person-situation interactionist model. Academy of Management Review, 11(3), 601-617.

Vogel, L. R. (2012). Leading with hearts and minds: Ethical orientations of educational leadership doctoral students. Values and Ethics in Educational Administration, 10(1), 1-12.

Watson, D. (2007). Does higher education need a Hippocratic oath? Higher Education Quarterly, 61(3), $362-374$.

Wilcox, J. R., \& Ebbs, S. L. (1992). The leadership compass: Values and ethics in higher education. Washington, D.C: School of Education and Human Development, George Washington University. ASHEERIC Higher Education Reports (ED 350970).

Wilder, C. S. (2013). Ebony and ivy: Race, slavery and the troubled history of America's universities. New York: Bloomsbury Press.

Wise, P. M. (2014a). Diversity strengthens excellence and innovation. Inclusive Illinois Impact Report 2014. Retrieved from http://inclusiveillinois.illinois.edu/files/impactreport_2014.pdf

Wise, P. M. (2014b). The principles on which we stand. Retrieved from https://illinois.edu/blog/view/1109/115906

Wood, G., \& Rimmer, M. (2003). Codes of ethics: What are they really and what should they be? Iona College, Hagan School of Business, and with the cooperation of St. Edmund Hall, University of Oxford.

Wright, D., \& Miller, M. (2007). Training higher education policymakers and leaders: A graduate perspective. Charlotte, NC: Information Age Publishing.

Wurth, J. (2015). Judge rules Salaita's employment lawsuit against UI can proceed. The News-Gazette. Retrieved from http://www.news-gazette.com/news/local/2015-08-06/updated-judge-rulessalaita $\% \mathrm{E} 2 \% 80 \% 99$ s-employment-lawsuit-against-ui-can-proceed.html

Wurth, J., \& Hettinger, J. (2015). Wise's resignation stuns campus. The News-Gazette. Retrieved from http://www.news-gazette.com/news/local/2015-08-07/wises-resignation-stuns-campus.html

Young, I. (1990). Justice and the politics of difference. Princeton, N.J.: Princeton University Press.

Zwick, R. J., \& Himelfarb, I. (2011). The effect of high school socioeconomic status on the predictive validity of SAT scores and high school grade-point average. Journal of Educational Management, 48(2), 101-121. 


\section{Biographies}

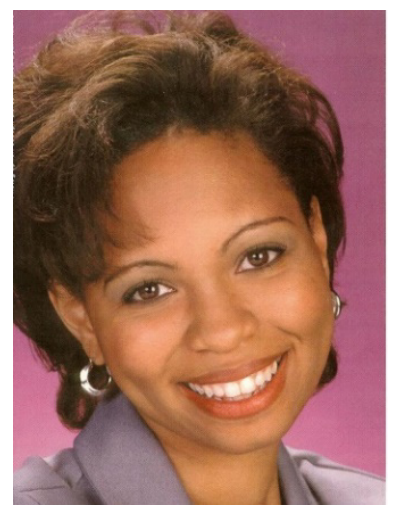

Dr. Crystal Renée Chambers is an Associate Professor of Educational Leadership at East Carolina University where she teaches courses in higher education law, policy and ethics.

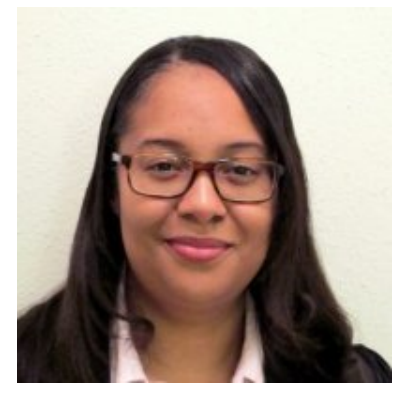

Dr. Hellen Ransom is an Associate Professor at East Carolina University's Brody School of Medicine. She holds a doctorate in healthcare ethics from Duquesne University. 